\title{
An Evaluation of the Legal and Regulatory Framework for Public-Private Partnership (PPP) in Nigeria
}

\author{
Victor Nonso Enebeli, Esq. PhD* \\ David Chibuike Njoku, Esq.**
}

\begin{abstract}
The privatisation of its industries and utilities started in Britain in the early 1980s and since then the private sector became involved in the ownership, operation and management of public assets and the provision of infrastructure services. The era of government providing singlehandedly providing infrastructural development and facilities are long gone. Government all over the world in this present dispensation cooperate with private sectors in the provision and management of various infrastructural facilities in their respective countries. Privatisation and economic liberalization became a standard policy prescription by international development institutions for most developing economies. The most common form of private investment in infrastructures has been the Public-Private Partnership (PPP). The success or otherwise of PPP in delivering infrastructure in developing societies such as Nigeria has, however, been a vexed issue. Since 1998, Nigeria has enacted a number of laws to regulate private investment in infrastructure development. One reason why policymakers opt for PPP include the need for the government to tap from private sector skill and expertise, the necessity for the public sector to concentrate on policymaking as well as the urgency to meet the increase in demand for infrastructure An examination of the legal and institutional framework for private sector investment in infrastructure assets and services and its prospects for Nigeria and other developing countries would be undertaken in this paper.
\end{abstract}

Keywords: public-private partnership, infrastructural development, Nigeria

DOI: $10.7176 / \mathrm{JLPG} / 118-05$

Publication date: February $28^{\text {th }} 2022$

\subsection{Introduction}

Physical infrastructure is an essential component of public goods which is supposed to be provided by a sovereign state. The provision of physical infrastructure has always been the responsibility of the state because infrastructure development involves huge sunk costs and initial investments which the private sector cannot or would not be very willing to provide. This was, however, until the late 1970s and early 1980s when the global economy witnessed a slump causing countries to experience balance of payment crisis and budget deficits. The economic meltdown of the past few years have also heightened the challenges faced by government in providing needed infrastructural services. Due to these and other factors, such as high cost of borrowing, governments now find it difficult to fund construction of infrastructure projects and there has consequently been an increasing recourse to the private sector.

The level of a country's infrastructural development and the level of its economic growth are somewhat interconnected. Nigeria's state of economic perplexity and uncertainty can be inextricably linked to the country's infrastructure deficit. According to the World Bank, in 2017, the total financing requirements to close the infrastructure gap in Sub-Saharan Africa alone, is about US $\$ 92$ billion per annum. ${ }^{1}$ In spite of Federal Government's efforts not even half of this target is met every year. Experts recommend focusing on core infrastructure such as roads, airports, electricity, mass transit, drainage, and water systems which are the life wire for the productivity of the economy. Ayasonla and Abiru in their work pontificated that infrastructure matters to economic growth has long ceased to form a subject of debate among experts and policy makers. They further stated that, indeed, a plethora of anecdotal and more technical evidence that better quantity and quality of infrastructure can directly elevate the fecundity of human and physical capital and ergo economic development.

This paper examines the regulation of PPP in Nigeria. In doing so, it needs to be pointed out that the aim of the paper is aimed at analyzing and highlighting the legal and institutional frameworks PPP in Nigeria to investigate the practice under the various PPP laws and to suggest improvements in the practice.

\subsection{What Is Public-Private Partnership (PPP)?}

There is no specific definition of the term public-private partnership. However, according to National

\footnotetext{
*Victor Nonso Enebeli, Esq. LLB(Hons)(London Met), LLM \& PhD(Coventry), B.L.,(Abuja), MCIArb (UK), Lecturer, Faculty of Law, Rivers State University, Port Harcourt, Rivers State. Email Address: victor.enebeli@yahoo.co.uk. Phone No: 09020176657

** David Chibuike. Njoku, Esq. LL.M (RSU) in-view; BL (Abuja); LL.B (UK); Dip-in-Law (UK), ACIArb (UK) Senior Associate Tuduru Ede, SAN \& Co. Port Harcourt, Rivers State, Nigeria. Email address: david.chibuike22@yahoo.com 08065357894, 08052339985

${ }^{1}$ World Bank Group, 'Africa's Pulse' (2017) No. 16 https://openknowledge.worldbank.org/handle/10986/28483 accessed 15th August, 2021
} 
Policy on public-private partnership of the Federal Government of Nigeria, PPP is defined as a contract, whereby the private sector is engaged by the public sector to manage some public services, and to design, build, finance and operate some infrastructure to enhance efficiency, broaden access, and improve the quality of public services. In such arrangement, it is the role of the public sector to plan and structure projects, while the private sector directly implements and executes the project. According to the work of Oni and Akinbinu, a PPP is a contractual arrangement between the public sector and the private sector to achieve well-defined and shared objectives in a well-managed cost effective, efficient and sustainable manner. ${ }^{1}$

PPPs also entail a set of contractual agreements between the government and the private sector sponsor. These agreements which will entail a range of commitments such as government tariff policies, land access rights, issuance of licenses, compliance with off-take agreements and terms of payment if the government arbitrarily terminates the agreement involve the grant of rights to private sector operators to provide services usually provided by public bodies for a fee.

In 1992, Britain pioneered the public finance initiative (PFI) in which a private sector enterprise finances and constructs an infrastructure project such as prison, hospital and school and leases same to the public sector at a fee until it (private sector) defrays the cost of the project after which it reverts to the government. In 1992, then under a Conservative Government, the United Kingdom developed the PFI concept as a means to procure much needed public infrastructure and services using private sector finance instead of increasing borrowing or taxation. Over time, the term 'PFI' became frequently less used, being replaced with the Public Private Partnership (PPP) variant in which a private enterprise provides infrastructure services under market conditions for a period of time. PPP is now used by most governments around the world to provide needed infrastructure assets and services. The use of the PPP, especially in developing countries, became necessary due to burgeoning population and inadequate public funds. PPP is a term now common place internationally when referring to any government sponsored initiative or scheme which involves the use of private finance to facilitate the provision of public services or social infrastructure. ${ }^{2}$

In Nigeria, the concept of PPP did not gain the momentum most western countries had until the turn of the new millennium due to heavy reliance on government funding in infrastructure development. In 2005, the Nigerian government enacted the Infrastructure Concession Regulatory Commission (ICRC) Act which regulates the practice of PPP in Nigeria. The Act did not, however, define PPP, but rather defined 'concession' to mean 'a contractual arrangement whereby the project proponent or contractor undertakes the construction, including the financing and the operation and maintenance thereof and shall include the supply of any equipment and machinery for any infrastructure. ${ }^{3}$

The commonalities in PPP across the globe are: the need for the public sector to save money without negatively impacting on the quality of public sector services; the availability to government/public sector bodies of advantageous accounting treatment for PPP projects; and the need to improve delivery times for greenfield infrastructure. ${ }^{4}$

To ensure the government receives 'value for money' in any PPP arrangement, it is imperative that the right partner is procured. The process for appointing the PPP partner is known as procurement. Procurement is 'the whole process of acquisition from third parties of goods, services and construction works. This process spans the whole life from the initial concept and definition of business needs through to the end of the useful life of an asset or end of service contract. ${ }^{5}$

\subsection{PPP Program Objectives}

Governments pursue PPP programs for different reasons. Some countries begin using PPPs to resolve a crisis or remove bottlenecks in a particular sector. For example, PPPs were first used in South Africa in the roads sectors to build more highways. In Philippines, many of the first PPPs were in the power sector, where the state-owned power company contracted with independent power producers to solve a power crisis. In both cases, the use of PPPs subsequently extended into other sectors. ${ }^{6}$

Most governments define broad PPP program objectives when formulating and documenting their PPP policies. The choice and relative priority of these objectives cascade from the government's other policies and priorities. They can include:

- Enabling more investment infrastructure, by accessing private finance

\footnotetext{
${ }^{1}$ Oni B and Akinbinu, 'Public-Private-Partnership in the Nigerian Development,' cited in Marcus, S. N. A. Sesan, Ayodele, and Iwu Hyacinth Nnaoma, Public-Private-Partnership: Proposed Nigerian Reform Programme for Electricity Development, American Journal of Humanities and Social Sciences, Vol. 3, No. 1, 2015, 13 - 17

${ }^{2}$ Derby, Modupe; 'Infrastructure Concession Regulatory Commission Act: Nine Years After,' Thisday (25-02-2014), p. 6.

${ }^{3}$ L. Onoja, 'An Examination of the Institutional Framework of Public-Private-Partnership in Nigeria.'

${ }^{4}$ Ibid

${ }^{5}$ Ibid

${ }^{6}$ PPP Program Objectives www.pppknowledgelab.org accessed $10^{\text {th }}$ January 2022
} 
- Putting a greater focus on the quality of service to the end-user

- Accessing additional management capacity through private operation of infrastructure

- Improving accountability in the provision of infrastructure and public services

- Harnessing private sector innovation and efficiency

- Stimulating growth and development in the country

- To deliver improved services and better value for money, primarily through appropriate risk transfer, encouraging greater asset utilization and an integrated whole-of-life management, underpinned by private financing ${ }^{1}$

- Some studies show that private infrastructure projects offer better quality at a lower cost than public infrastructure projects due to the different incentive structure

- In light of the hypothesis that not building a facility due to limitations in the public budget may represent certain opportunity costs in terms of growth and development, some countries (such as Germany and the United Kingdom) that had previously rejected private financing initiatives for infrastructure projects are now adapting the necessary laws and procedures to allow for this in their long term planning

- $\quad$ To encourage the use of principle where users pay for services received; or in certain cases the paying ability of the users shall be taken into consideration and also to ensure that Private Investment in infrastructure projects allows for the fiscal consolidation of the public budget freeing resources for other social expenditure items or to reduce tax pressures.

\subsection{PPP is Not Privatization}

There is often confusion between privatization and PPPs. There is is however a clear difference between these two forms of private sector engagement. In its true sense, privatization involves the permanent transfer to the private sector of a previously publicly-owned asset and the responsibility for delivering a service to the end user. However, a PPP necessarily involves a continuing role for the public sector as a "partner" in an ongoing relationship with the private sector (World Bank - Farquharson, Torres de Mastle, and Yescombe, with Encinas 2011).

Confusion can arise because sometimes the term "privatization" is used more broadly; for example, to mean any form of private management. When used in this way, the term can apply to a wide range of arrangements, including PPPs. However, for the purposes of this PPP Work, privatization is defined in its true sense as described above, and under this definition PPPs are not privatizations. ${ }^{2}$ By definition, privatization is not an option for governments to procure new infrastructure, as privatization implies the infrastructure has already been constructed.

Similarly, the contracting out of management of existing infrastructure is not privatization because it does not involve a permanent transfer of that infrastructure to the private sector. In addition, there is a continuing role for the public sector as a "partner" in an ongoing relationship with the private sector.

Private party is the term selected to refer to the private sector agent(s) or participant(s), meaning the company or companies that will act as a "private partner" in the "partnership" (that is, the PPP contract). This private partner is the contractual counterparty of the "public party" and will usually be a project company that may also be named as a Special Purpose Vehicle (SPV), such as a company constituted specifically for the purpose of signing the contract and managing the project. ${ }^{3}$ The public party concept is intended to include either governments (the respective procuring authority), agencies companies or entities that may act in the respective contract as procuring authorities in the name of the government.

\subsection{Infrastructure: Meaning and Importance to Economic Growth}

Infrastructure is the basic physical and organizational structures needed for the operation of a society or enterprise. The term typically refers to the technical structures that support a society, such as roads, water supply, sewers, power grids, telecommunications, and ports. It is the set of interconnected structural elements that provide the framework supporting an economy. Infrastructure is important for faster economic growth and alleviation of poverty in the country. The adequate infrastructure in the form of road and railway transport system, ports, power, airports and their efficient working is also needed for integration of the Nigerian economy with other economies of the world.

It needs to be emphasized that good quality infrastructure is important not only for faster economic growth but also ensure inclusive growth. This means that the benefits of growth are shared by the majority of the people of a country. Thus the inclusive growth will lead to the alleviation of poverty and reduction in income inequality

\footnotetext{
${ }^{1}$ PPP Program Objectives www.pppknowledgelab.org accessed $10^{\text {th }}$ January 2022

${ }^{2}$ APMG International, 'Defining PPPs for the Purpose of This PPP Guide' www.ppp-certification.com accessed $15^{\text {th }}$ January 2022

${ }^{3}$ Ibid
} 
in the country. For example, micro, small and medium enterprises (MSME) are dispersed throughout the economy and production by them and their growth require access to quality and reliable infrastructure services to compete efficiently with large - scale enterprises which can often build some of their own infrastructure such as installing their own small power plant generators. Besides, large scale firms can even locate themselves near ports and near transport hubs where required infrastructure is available. ${ }^{1}$

Small enterprises, on the other hand, are dispersed widely in the economy and have to rely on the availability of the general infrastructure facilities. Thus, by building up general infrastructure facilities helps the small enterprises to compete successfully with large - scale industries and being labor-intensive generate large employment opportunities for the workers. This will help to alleviate the poverty in the developing countries and improve their economy.

The expansion in infrastructure facilities such as irrigation, rural electrification, roads and road transport will promote agricultural growth and setting up of agro-processing industries. These general infrastructure facilities will help farmers and owners of processing industries to get their requirements of raw materials, fertilizers and other inputs at cheap rate and also help them bring their products to the markets which are located in big towns and cities. ${ }^{2}$

Lack of adequate infrastructure not only holds lack of economic development, it also causes additional costs in terms of time, accessing essential social services such as healthcare and education. Emphasizing the importance of adequate infrastructure, authors of Economic Survey of India for the year 2013 - 2014 quite rightly write, "Rural economic growth in recent years has put enormous pressure on existing infrastructure particularly on transport, energy and communication. Unless it is significantly improved infrastructure will continue to be a bottleneck for growth and obstacle to poverty reduction". In other words, it is the challenge to ensure strong, sustainable and balanced development through integration of the economy with environmentally sustainable development of infrastructure. It is the brick and mortar and the foundation of any nation's industrial evolution and economic prosperity. Modern industry and commercial activities rest on developed and efficient infrastructure. Industrialized economies such as China, and advanced economies such as the United States embark on ambitious investments in infrastructure to create jobs and restore or sustain growth.

\subsection{Nigeria's Infrastructure Deficit}

It is estimated in the National Infrastructure Master Plan that an investment of over \$2.9 trillion (N460 trillion) is required for the next 30 years in Nigeria's infrastructure and that a yearly average of $\$ 25.2$ billion (N4 trillion) investment is required over the next five years. ${ }^{4}$ The Federal Government's allocation to capital projects in the 2014 budget was 27 percent, representing N1.1 trillion. ${ }^{5}$

Government needs private sector funding to supplement infrastructure financing in Nigeria. But Nigeria has to be realistic in her expectations. The private investors she wishes to attract are often foreign institutional investors who must account to their clients for their investment decisions. They need to be in a position to make a calculated assessment of the risks involved in their investment, be satisfied that they are working with reliable data, be reasonably comfortable that their capital is secure and be comfortable with the level of political risk they take on.

The construction of Nigeria's infrastructure involves significant risks for foreign investors. Nigeria does not have a track record of executing PPP transactions, or good record for good governance and transparency in her corporate affairs, and political and security risk remain high. It will therefore come as no surprise when private investors seek extensive guarantees that drive up the cost and timeframe of projects in Nigeria.

It may be better to finance the construction of projects using public resources and, following construction, to seek refinancing from private investors. Nigeria must start creating enabling, secured and safe environment for foreign investors and engage in the process of building her core infrastructure from her own resources while simultaneously preparing the framework for engaging with private investors at a later stage and on terms that work better for the country.

\subsection{Some Major PPPs in Nigeria}

In 2006, the federal government of Nigeria implemented the port reform programme and twenty-six (26) port terminals were concessioned to private terminal operators under long-term contracts. The concessions were part of a larger plan to repeal the Nigerian Ports Authority Act and establish a new Ports and Harbours Authority with powers to grant concessions to private entities and conduct technical regulation of the port industry. Also in the

\footnotetext{
${ }^{1}$ J. Ayesha, 'Infrastructure: Meaning and Importance to Economic Growth'https://www.economicsdiscussion.net accessed 19 January 2022 ${ }^{2}$ Ibid

${ }^{3}$ Ibid

${ }^{4}$ See the National Integrated Infrastructure Master Plan, launched in December 2013.

${ }^{5}$ Uwaifo, Elizabeth; 'Private Investment in Infrastructure Development,' The Nation (23-06-2014), p. 21.
} 
pipeline is the establishment of an independent regulator for the transport industry. ${ }^{1}$

Due to the success of the port concessions, two major roads in Lagos, the Lagos-Ibadan Expressway and the Lekki-Epe Road, were concessioned to private companies by the federal and Lagos State governments, respectively, as the government experimented with toll roads. A major airport terminal in Lagos, the MM2, was also concessioned to a private company. This was a concession/BOT to build a new domestic terminal and additional facilities at the Murtala Muhammed Airport (MMA2) in Lagos. MMA2 was the first major BOT infrastructure project to be contracted by a Nigerian company. In 2013, Bi-Courtney was awarded the contract with 12years tenor initially later extended to 36 years. The contracting parties were the aviation Minister, Federal Airports Authority of Nigeria (FAAN) and Bi-Courtney. About six banks were involved in this syndicated loan and project financing. ${ }^{2}$ The project bump into a number of problems, among which are inability to secure long term financing agreement, and reluctance of FAAN to maintenance the project by enforcing use of MMA2 by airlines as required in the PPP agreement, couple with several claims of breach of contractual rights by both parties. Also, the nonexistence of relevant dispute resolution mechanism for PPP projects leading to escalation of controversies easily and the failure of FAAN's to comply with several court orders, and inability of ICRC to shield PPP projects and private investors.

There are plans to concession the remaining airports to private operators and a project pipeline has been drawn up by ICRC. The above attempts at PPP met with mixed results, however, as the institutional framework was lacking.

\subsection{Legal and Regulatory Framework for PPPs in Nigeria}

The federal government of Nigeria initiated and enacted various sectoral and cross-sectoral laws which include the Infrastructure Concession Regulatory Commission Act (2005), the Public Procurement Act (2007), the Privatisation and Commercialisation Act (1998), and the Electricity Sector Reform Act (2005) in pursuance to its economic reforms. The aim of the above statutory initiatives is to open up the infrastructure sector for private investment and abolish public sector monopoly of the provision of infrastructure service. By so doing the economy should benefit from transfer of needed private sector finance, management skills and technology.

The 1999 Constitution guarantees to citizens of Nigeria freedom of private enterprise. Freedom of private enterprise connotes the absence of state monopoly of business activity with an exclusiveness conferred by law, as well as absence of unwarranted state regulation of private enterprise. An economy under which the means of production and distribution are publicly owned and managed to the exclusion of private persons, or which may be regulated by the state as it likes, is the antithesis of private freedom. ${ }^{3}$ The-state-must-control-thecommanding-heights-of-the-economy paradigm has now been consigned to history. A highlight of some PPP legislations in force since 1999 is stated and explained below.

\subsubsection{Infrastructure Concession \& Regulatory Commission Act, 2005}

Recognizing the need to stimulate PPPs in Nigeria, the government passed the Infrastructure Concession and Regulatory Commission Act, 2005. The Act which was generated in the context of Nigeria's interest in an overall agenda of privatization and private participation in infrastructure service and delivery was enacted to provide the legal framework for Nigeria's PPP programme. The explanatory memorandum to the Act states:

'this Act provides for the participation of private sector in financing the construction, development, operation or maintenance of infrastructure or development projects of the Federal Government through concession or contractual arrangements; and the establishment of the Infrastructure Concession Regulatory Commission to regulate, monitor and supervise the contracts on infrastructure or development projects.

The ICRC Act contains two major sections:

i. The first section provides for any government agency to enter into a PPP arrangement with a private sector party to develop, finance, construct, maintain and operate infrastructure services or facilities. The section provides general outlines on the prioritization of projects, the authorizing channels for guarantees on concession agreements, competitive and non-competitive public bidding procedures, duration of concessions, recovery of investment, authentication of project cost, and project supervision.

ii. The second part of the Act establishes the Infrastructure Concession Regulatory Commission (ICRC). The ICRC is managed by a 12-member board that includes a part-time Chairman, the AttorneyGeneral of the Federation, the Minister of Finance, the Secretary to the Government of the Federation, the Governor of the Central Bank of Nigeria, one person from each of the six geographical zones of Nigeria with experience and expertise in law, business administration, engineering, economics or public administration and two of whom shall be women, and the

\footnotetext{
${ }^{1}$ L. Onoja, 'An Examination of the Institutional Framework of Public-Private-Partnership in Nigeria.'

${ }^{2}$ E. Uwem and Y. Abubakar, Public Private Partnership and Sustainable Development of Infrastructures in Nigeria. Advances in Management \& Applied Economics, 3(6), 2013.

${ }^{3}$ Nwabueze, B. O.; The Presidential Constitution of Nigeria, C. Hurst \& Company, London, UK, 1982.
} 
Director-General of the Commission. The Commission's main functions are to take custody over every concession agreement and ensure the efficient execution of any concession agreement or contract entered into by the Federal Government.

The ICRC was established to provide for the participation of the private sector in financing the construction, development, operation, or maintenance of infrastructure or development projects of the federal government through concession or other contractual arrangements. The scope of the federal government's PPP programme includes development projects, which before the commencement of the ICRC Act were financed, constructed, operated or maintained by the federal government and which after the commencement of the Act, may be wholly or partly implemented by the private sector in the areas of power plants, highways, seaports, airports, dams, hydroelectric power plants, water supply, railway, housing, ICT, tourism, health, etc.

The Act also provides for MDAs of the federal government to enter into contracts with or grant concession to any duly pre-qualified private sector proponent for the financing, construction, operation and maintenance of any infrastructure or any development facility of the federal government that is financially viable.

The ICRC Act, 2005 confers the Commission with powers to:

- $\quad$ Provide general policy guidelines, rules and regulations.

- Take custody of every concession agreement granted over federal government infrastructure.

- Ensure efficient execution of any concession agreement or contract entered into by the federal government over its infrastructure.

The ICRC Act is the closest legal instrument that Nigeria has to a comprehensive infrastructure law. Gaps, however, remain in the Nigeria legal framework that may impede the PPP regime. First, the Act gives MDAs power to enter into PPP agreements, following approval of the Federal Executive Council, without any mention or consideration of the other entities of government that may be impacted by such agreements or other applicable legislation. There is no mention of the need to take into account the impact of proposed PPP transactions on federal government finances.

There is also lack of consistency and precision in the definitions. The term 'public-private partnership' is not mentioned and the definition of infrastructure is too broad.

It is noteworthy that the Act does not provide for the ownership of infrastructure assets by the private sector, nor does it provide for private sector operators to collect fees from the general public for the use of infrastructure assets, nor does it provide for the possible acquisition of land.

Another gap in the Act is that the Act is not clear regarding the approval process for PPP projects and, in particular, the granting of a concession.

Again, the powers of the Commission are relatively weak and are limited to taking custody of already signed agreements and monitoring them. There is no specified role for the Commission in the evaluation/tendering process for PPP projects and no mention of the relationship and coordination between the Commission and other agencies that may have a role in monitoring such contracts.

Another pitfall of ICRCA is that it is limited in its discussion of coordination between public sector bodies involved in PPP projects.

There is lack of reference to the scale of projects to be considered for private sector participation in the said Act.

The Act does not treat the issue of unsolicited proposals. In the early stages of the development of a PPP market, many governments find themselves in receipt of a considerable volume of 'unsolicited bids.' These are commercial proposals that are submitted to the government by private sponsors. At best, these 'bids' can offer some early movement on investments and bring some needed funding. At worst they can lead to a significantly over-priced misallocation of resources. Absence of a sufficiently robust process of public choice (unsolicited bids are generally not in response to a government-developed and appraised programme of priority public investments) and lack of competitive selection are the main factors behind the more frequently 'negative outcome' that derive from unsolicited bids.

There is an absence of provisions for a fair, efficient appeal process for illegal awards or aggrieved parties.

The Act makes no mention of a proper audit/review of processes and outcomes or to the need for proper public financial management. Unfortunately also, no provisions are made in the ICRCA for alternative dispute resolution mechanisms. ${ }^{1}$ Misunderstandings and disputes are inevitable between parties involved in PPP transactions and alternative dispute resolution mechanisms would have offered several ways of settling such misunderstanding and disputes in business in a less painful and more accommodating manner than the adversarial way of settling issues through the judicial process or litigation in a court of law. ${ }^{2}$

In order to make the regulatory functions of the Commission more effective, the ICRCA should have contained a provision that any PPP transactions done without compliance with the ICRCA would be unlawful.

\footnotetext{
${ }^{1}$ Ahmed "Infrastructure development for Nigeria-the PPP imperative" ICRC website-http://www.icrc.gov.ng/ accessed $19^{\text {th }}$ January 2022.

${ }^{2}$ Ibid
} 
In relation to the functions, the legislation lacks the regulatory and enforcement provisions that are vital in delivering the Commission's mandate. ${ }^{1}$ The statutory functions are somewhat restricted in scope in a number of instances.

Also, the functions of the Commission are also limited in scope. The Commission's role is limited to monitoring and ensuring compliance of post-transaction activities. Other limitations in the scope of functions of the Commission are:

a. The functions refer only to concession and not to other forms of agreement for the private sector provision of infrastructure services.

b. The ICRC Act does not refer to the role of the Commission as it relates to evaluating or approving proposals, and makes no reference to processes for preparing or analyzing projects or for deciding which projects should be prioritized by federal agencies.

c. The word 'Regulatory' in the title of the Act and in the title of the Commission is misleading as the Commission does not have any powers of industry regulation and is not intended to not have such powers.

d. There are no specific links to any other legislation impacting infrastructure, including how the Public Procurement Act, 2007 will impact on PPP procurement processes.

The ICRC was commissioned in 2008 together with the appointment of the Director General and charged with the responsibility of acting quickly to bring together the ministries, departments and agencies (MDAs) in support of the programme. The ICRC has been collaborating since then with the MDAs to build support and a clear understanding of the institutional role of the ICRC in stimulating PPPs in Nigeria.

The Federal Executive Council (FEC) approved the National Policy on Public Private Partnerships in April 2009. This policy document is intended to ensure adherence to best practices and set forth standards by which the federal government engages in PPP transactions. Central to this are provisions for the institutional framework on how federal government will reinforce the accountability of MDAs for the delivery of public services and how these responsibilities will be divided between the key MDAs with respect to the sector-specific PPP project.

Likewise, the PPP policy sets the standards for PPP financial framework including provisions for value-formoney analysis, assessment of project risk, unsolicited bids, and proper procurement procedures. The following key principles have been established by the Commission in its guidelines for PPP:

$\circ$ Achieving the best value for money in public services at all stages of a project's development and procurement by taking into account costs, risks and service quality;

$\circ$ Whether the financial investment is substantial enough to justify the involvement of the private sector;

- Financial viability of the project to ensure that the private investor is able to recoup the cost of its investment;

- Secondary benefits such as the generation of employment, enhancement of revenues of government through taxes and facilitation of commerce and commercial activities;

- Allocating risks to parties best able to manage them;

- Ensuring transparency and openness in the procurement process through fiscal discipline, corporate governance and competitive bidding process; and

- Consideration that public interest is protected by ensuring adequate consultation with end-users and other stakeholders and mitigating socially unacceptable outcomes of proposed projects.

The ICRC has no pre-contract role except to publish the list of projects eligible for concession. The Act does not specify any process for preparing or analyzing projects or for deciding on priority projects as mentioned in Part II of the Act. The Act makes no reference to how it would interact with other existing Acts such as the Privatisation Act. It is not clear whether the ICRC Act seeks to provide a separate legal regime for temporary transfer (concession, lease, etc.) of activities of a public agency with respect to public infrastructures whilst the Privatisation Act would be limited to permanent transfer of ownership of assets or shares of public enterprises.

The ICRC Act gives MDAs powers to grant concessions or enter into contracts with respect to infrastructure projects which include electric power projects. The powers vested in MDAs under the ICRC Act are without reference to the National Council on Privatisation (NCP) and without regard to the Public Enterprises (Privatisation and Commercialisation) Act, 1998 which was an existing law at the time the ICRC Act was passed. The ICRC Act clearly creates a conflict with the Privatisation Act and Electric Sector Reform Act, 2007 especially in terms of role overlap between NCP and the MDAs as well as the ICRC which may affect investors' confidence.

The Act does not also make provision for PPP units. However, National Policy on Public Private Partnerships (PPP), 2009 recognizes the need for a central PPP unit and states government proposal to create a PPP Resource Centre within the ICRC to 'play an important part in the institutional framework that the government is creating to support its PPP policy. 
The ICRC Act seeks to provide a legal framework for PPPs but is full of inconsistencies and conflicts leaving an impression that it was made without any clear understanding of the purposes for which the law is required and the context in which the law will exist. There was no policy prior to the enactment of the Act in 2005 to clarify the rationale for and the circumstances in which the granting of a concession or a PPP would be adopted. The subsequent National Policy on PPP appears to state federal government's commitment to review the legal and regulatory framework created under the ICRC Act and other existing laws. But it appears to be an afterthought.

To ensure consistency with the Public Good and a sufficient volume of competitive, least cost PPP outcomes, there needs to be in place an enabling environment that serves the following two requirements: first, establishes a policy framework setting out government objectives, principles and coherent implementing arrangements to support PPP approaches; and second, ensures consistent legal and regulatory arrangements notably in terms of:

i. PPP procurement procedures and practices-including how to address the limitations of unsolicited bids;

ii. Sector (power, telecoms, roads, ports) legislation in terms of how PPPs are to be implemented in these different sectors and how sector regulators are to coordinate with other regulatory players in the PPP space; and

iii. Fiscal approaches to issues such as government guarantees and contingent liability management arrangements

\subsubsection{Electric Power Sector Reforms Act, 2005}

The Electric Power Sector Reforms Act 2005 was signed into law on 11 March 2005. Generally, it provides the statutory framework for participation of private companies in electricity generation, transmission, and distribution. Specifically, the Act provides for the formation of companies to take over the functions, assets, liabilities and staff of the defunct National Electric Power Authority (NEPA). It also provides for development of competitive electricity markets and the establishment of the Nigerian Electricity Regulatory Commission (NERC). Besides, the Act also makes provision for the licensing and regulation of the generation, transmission, distribution and supply of electricity. Regulatory issues in respect of enforcement of matters like performance standards, consumer rights and obligations and determination of tariffs are also governed by the Act. ${ }^{1}$

Section 1 of the Act provides for the transformation of the defunct NEPA to the Power Holding Company of Nigeria (PHCN) which was then unbundled into autonomous companies comprising of: One transmission company, seven generation companies and eleven distribution companies. Part of the reforms which was provided for in the Act was the establishment of the NERC, the Rural Electrification Agency (REA) and the National Electricity Liability Management Company (NELCO) - a special purpose vehicle expected to take over and manage the residual assets and liabilities of the defunct NEPA, after privatisation of the unbundled companies. Section 83 empowers the Commission to set up and administer a fund under the name: "Power Consumer Assistance Fund" to be used to subsidise under-privileged power consumers as may be specified by the appropriate minister. ${ }^{2}$

\subsubsection{Public Enterprises (Privatization and commercialization) Act, 1999}

The BE Privatization Act of 1999 was aimed at restructuring the economy of Nigeria and making it competitive and efficient. The restructuring of public enterprises was an integral part of the Structural Adjustment Programme, in 1986.

The essence of the Act is to provide for privatization and commercialization of certain public enterprises and to establish the National Council on Privatization and the Bureau of Public Enterprises. ${ }^{3}$ Following the enactment of the Public Enterprises Act of 1999, the Bureau of Public Enterprises (BPE) was formed to take over the activities of the Technical Committee on Commercialization and Privatization (TCPC). ${ }^{4}$ The Act also made provision for the establishment of the National Council on Privatization (NCP). ${ }^{5}$ The NCP is the lead policy making body in charge of privatization and commercialization in Nigeria.

The Public Enterprises Act, 1999 empowered the BPE to change emphases from commercialization to encourage core investors, and promoting foreign investment in privatization programme. ${ }^{6}$ In some cases like the Nigerian Port Authority, BPE employed concessioning rather than outright privatization. Concessioning entails allowing some private company to run ports for five to ten years. The company is automatically granted some level of ownership right. This is in tandem with the provisions of sections 1 (a) - (b) and section 6 (1) and (2) of the Act that provides for partial and full privatization and commercialization of public enterprises in Nigeria.

\subsubsection{Public Procurement Act, (PPA) 2007}

\footnotetext{
O. Soyeju, Legal Framework for public private partnership in Nigeria

2 EPSR Act 2005, s83

${ }^{3}$ PE Act 1999, chapter p38.

${ }^{4}$ Ibid, s12.

${ }^{5}$ Ibid, s9.

${ }^{6} \mathrm{PE}$ Act $1999, \mathrm{~s} 14$
} 
In carrying out development activities and implementing their national budgets, governments must procure goods, materials and services from private sector individuals and organizations. In order to obtain the best possible value and ensure an equitable and efficient deployment of public resources, some governments have adopted a range of policies and procedures that, hopefully, guarantee the lowest price and optimum quality supply. The core feature of a system that achieves these goals is competition amongst various prospective providers of goods and services to government and her agencies, in much the same way that competition in the consumer segment of the economy drives down prices and fosters higher quality goods and services to the public. The Public Procurement Act, 2007 was conceived along the lines of this basic logic.

The primary goal of the PPA, 2007 is "establishment of National Council on Public Procurement and the Bureau of Public Procurement (BPP). The essence is to monitor and have an oversight function over public procurement, harmonizing the existing government policies and practices, framework and professional capacity for public procurement in Nigeria, and for other related matters". ${ }^{1}$

The Federal Government of Nigeria and all Procurement Entities which derive at least 35\% of funds appropriated for any type of procurement described from the Federation Share of consolidated Revenue Fund. However, this shall not apply to procurement of Special Goods, Works and Services involving national defence. ${ }^{2}$

The BPP was established to curb wastage and reduce fraud in the procurement of goods and services in government agencies. Some of the functions of the Bureau include the formulation of general guidelines and policies relating to public sector procurement for the approval of the Council; to certify federal procurement prior to the award of contract; supervise the implementation of established procurement policies; monitor the prices of tendered items and keep a national database of standard prices; publish paper and electronic editions of the procurement journal and maintain an archival system for the procurement journal. The Bureau also has the function of preventing fraudulent and unfair procurement and where necessary apply administrative sanctions such as the refusal to issue a certificate of 'No Objection' for contract award.

The core objectives of the Act are to ensure economy and efficiency, competition providing level playing ground for all strata of bidders, value for money and transparency. The Act vests on the BPP with the responsibility to amongst others, provide legal and institutional framework and Professional Capacity for public procurement in Nigeria. ${ }^{3}$

The Act vests the BPP with the responsibility of harmonizing existing government policies and practices on public procurement and purchases and ensuring probity, accountability and transparency in public procurement processes. ${ }^{4}$ Also, the Bureau has the responsibility of establishing strict pricing standards and benchmarks for the implementation of public procurement by concretizing general standards for procurement of goods, services or the award of contracts by all federal government agencies and ministries, as provided by section 4 and section 17 of the Act. ${ }^{5}$

The National Council on Public Procurement (NCPP) is the policy arm for procurement regulation while the Bureau is the technical and operating arm with far-reaching objectives and powers which are to be exercised subject to the approval of the Council. The Bureau serves as the secretariat of the Council. NCPP's functions include considering and approving the monetary threshold for public procurement, a prior review of thresholds for the application of the provisions of the Act, and the consideration and approval of policies on public procurement.

The Act promised a couple of things: transparency, competitiveness, cost effectiveness, consistency, integration, fair-dealing, integrity, accountability, professionalism and value for money in public procurement. Value for money comes with its three components of economy, efficiency and effectiveness. Economy involves thrift and good housekeeping, acquiring resources for appropriate quantity and quality at the lowest cost. Efficiency ensures that maximum useful output is gained from the resources devoted to each activity or that only a minimum level of resources is devoted to achieving a given level of output. Money should not be spent simply because it was budgeted. Effectiveness ensures that output from any given activity or the impact of the activity or services is having the desired result. Essentially, government's spending should be seen to be achieving the stated sectoral objectives in education, housing, health, etc.

The focus of the Procurement Act is the traditional public procurement of goods, works and services. There is no express reference to infrastructure procurement or to public private partnerships (PPPs). Where the procurement of goods, works and services necessary for infrastructure services is involved the Act will apply but it is silent on the non-tender or concession aspects of PPP transactions. Nor is there any reference to unsolicited bids or to the interaction between procurement under the Act and the Procurement Regulations, on the one hand,

\footnotetext{
${ }^{1} \mathrm{~K}$ S Ikechi and Others, 'Effectiveness of PPA, in Curbing Corruption in the Public Service in Nigeria - A Study of Selected MDAs in FCT, Abuja https://researchleap.com accessed $22^{\text {nd }}$ January 2022 
and the PPP Policy, on the other hand. For instance, the conduct of due diligence by third party investors, the potential renegotiation of terms over the life of a project, financing by third party investors, the use of variant bids and the right of the Federal Government to step-in in the event that the contractor fails to perform are all matters that are specific to PPP projects but were not contemplated nor provided for by the Procurement Act or the Regulations.

A Project Continuity Bill which would establish a legal framework that would make it mandatory for any new government to finish the projects initiated by its previous administration was presented to the National Assembly. The Bill aimed to commit governments at all levels to projects and policies embarked upon by their predecessors. ${ }^{1}$ It was the plan of government to use the Bill to ensure that the Vision 20:2020 does not go the way of similar policies initiated by past governments in the country. The Bill shall also provide backing for longterm development plans to ensure continuity in planning and economic growth initiatives. The Bill was part of the recommendations of the Vision 20:2020 document. The Bill was meant to protect the Vision and institutionalize and legalize planning. The country needed some $\$ 32$ trillion in investments in order to actualize the Vision 20:2020 project. The fund will come from the three tiers of government with the federal government contributing N10 trillion, states and local governments $\$ 9$ trillion. The remaining $\$ 13$ trillion will have to be sourced from the private sector. ${ }^{2}$ Nothing has been heard of the Bill since, while Vision 20:2020 project was never realized.

There is an urgent need to strengthen the capacity of the nation's civil service. The existing institutional mechanisms such as the Budget Office of the Federation, the BPIU/Due Process Office (in the Presidency), the Fiscal Responsibility Commission and the Bureau of Public Procurement are for no other functions than capital project management and the enthronement of transparency and accountability in the execution of capital projects. The federal government should take a fresh look at what these different agencies of government as well as internal audit units of MDAs have been doing over the years, how compliant they have been with budget guidelines and financial regulations, and then fashion appropriate remedies for project management. ${ }^{3}$ Nonimplementation of capital budget is a by-word for failure in service delivery.

The PPA is so central to the economic revival of Nigeria to the extent that it regulates the capital component of the annual budget; and the annual budget is the most important economic tool for the transformation and reengineering of national life and securing of the wellbeing of the people. ${ }^{4}$ There is therefore a need for the BPP to use the PPA to ensure adequate implementation of the capital component of the budget by ensuring strict adherence to Public Procurement Act, 2007. The Bureau, however, averred that its job is to set the rules and guidelines that inform the procedures that a ministry must adopt before making its selection. Issue of feasibility of a project, contract execution or socio-economic value of projects is outside its jurisdiction.

A parastatal or agency is normally the implementing agency for PPP projects. Studying the law establishing the relevant agency in which a project is domiciled is imperative. The scope of powers conferred on the agency to enter into contract with private entities would greatly influence the outcome of the transaction.

About 12 states have so far enacted their own procurement and PPP laws. However, where there is conflict with a Federal enactment, the state law would give way.

International Finance Institutions such as the World Bank have their own procurement guidelines and these guidelines normally apply if credit from the Bank is involved in the financing or technical capacity building for a project normally apply if credit from the Bank is involved in the financing or technical capacity for building a project.

\subsubsection{Debt Management Office Establishment (Etc.) Act 2003}

The Debt Management Office (Establishment, Etc.) Act was enacted to establish the Debt Management Office $(\mathrm{DMO})^{5}$ which was established on $4^{\text {th }}$ October, 2000 to centrally coordinate the management of Nigeria's debt. The DMO is responsible, among other things, for the preparation and implementation of a plan for the efficient management of Nigeria's external and domestic debt obligations at sustainable levels compatible with desired activities for growth, development and participation in negotiations aimed at realising the objectives. ${ }^{6}$

It has specific responsibilities with respect to all loans and borrowings of the federal government and empowers the Minister of Finance to give guarantees for such borrowings and to approve loans from financial institutions to the Federal, State or Local Governments or any of their agencies. The establishment of the DMO was given statutory flavor with the enactment of the Debt Management Office (Establishment) Act, 2003. The functions DMO are spelt out in Sections 6 and 7 of the DMO Act, 2003 (as amended). They include advising the government on terms and conditions of loans, restructuring and refinancing; maintaining a complete and accurate

\footnotetext{
1 'Presidency Bids to Combat Abandoned Projects Menace,' (The Guardian, Nigeria, 24 October,), p. 1.

2 'Nigeria and Vision 20:2020,' (The Guardian, Nigeria, 21 June, 2010), p. 29.

${ }^{3}$ L. Onoja, 'An Examination of the Institutional Framework of Public-Private-Partnership in Nigeria.'

${ }^{4}$ Abel, Victor; 'Procurement Act and Capital Budget Implementation,' (Thisday, Nigeria, 21 May, 2012), p. 18.

${ }^{5}$ DMO Act, 2003 s 4

${ }^{6}$ Ibid s 1 \& s 8
} 
database of all sovereign borrowings (domestic and external) including contingent liabilities (guarantees); and preparing and submitting to the government, annually, a forecast of debt service and borrowing capacity. ${ }^{1}$ Other functions are efficient management of Nigeria's domestic and external debt stocks, including the financial and currency risks; managing relationships with local and international creditors and investors; issuing and managing sovereign securities issued publicly and publishing debt data.

Since all PPP processes may involve Federal Government borrowings guarantees and other long term contingent liabilities, by virtue of section 6 of the Act, the DMO's approval will be required. ${ }^{2}$

The DMO supervises the money and capital markets by ensuring that the two segments of the financial sector work perfectly together and develop the range of appropriate instruments that are needed to hedge financial risks in the PPP projects. An example of this is developing the secondary market for government bonds in both liquidity and depth and this will ultimately provide a reference interest rate for PPP financing. ${ }^{3}$

Since its inception, DMO has played a significant role in the management of the nation's debt stock. The exit from the Paris Club debt trap in 2005 was amply facilitated by the work of DMO which provided hitherto unknown data about Nigeria's debt profile. Nigeria paid her foreign debts and exited the Paris Club in 2006. Nigeria struck the debt write-off deal with the Paris Club of Creditors wherein Nigeria paid a sum of $\$ 12.4$ billion to the Paris Club in exchange for a debt write-off of \$18 billion. Nigeria's external debt profile before the Paris Debt write-off stood at about $\$ 35.5$ billion. After the successful debt relief initiative, Nigeria's stock of foreign debt declined dramatically. Indeed, in August 2006, Nigeria's foreign and domestic debts amounted to US $\$ 3.5$ billion and US\$13.8 billion respectively-a total of US\$17.3 billion or 11.8 per cent of GDP.

The debt profile is building up again. Nigeria's external debt stood at $\$ 22.08$ billion (as at June 30, 2018). The debt-GDP ratio is $17.8 \%$, which is below the $30 \%$ target set for the economy and below the $60 \%$ that is the international norm. Nigeria conducts a Debt Sustainability Analysis (DSA) on a yearly basis in conjunction with the World Bank and IMF. The DSA utilizes macroeconomic data to assess a country's debt sustainability in relation to current debt burden thresholds and project's its future ability to service its debt. The results from the DSA indicate that Nigeria is well within the debt sustainability threshold for all the years covered up to 2030 and is still at a low level of debt distress.

The DMO, on the basis of the above figures, gave the country a pass mark on debt sustainability and claimed that Nigeria was one of the least indebted countries among comparator nations. Debt sustainability is the ability of a borrower to repay her present and future borrowings in an orderly manner without accumulation of arrears. To assume sustainability, the borrower must have sufficient and adequate reserves that it might fall back on in case present or future revenue expectations are unrealized. The borrower also must be able to meet its debt obligations without constricting or constraining other budgetary obligations or commitments.

The states (sub-national units) seem to be facing a major financial crisis due to the rising debt profile of the states at both the domestic and external levels. The Debt Management Office (DMO) reported that 36 states of the federation as well as the Federal Capital Territory (FCT) were owing to the tune of $\$ 2.22$ billion (N333.05 billion) in external debts as at June 2011. This was viewed with concern since Nigeria only exited the Paris Club of Creditors on April 25th $2006 .{ }^{4}$ According to the World Bank, sovereign and sub-national debts have been growing in importance across the globe. In Brazil, for example, sub-national debt accounts for about $30 \%$ of total public sector net debt, while the debt of Indian states is about $30 \%$ of GDP. In Nigeria, the external debt of states at the end of June 2011 stood at about $42 \%$ of total external debt in Nigeria. ${ }^{5}$

Part of the DMO's mandate is to be satisfied that any contingent liabilities are manageable within the government's economic and fiscal forecast. To this end, the DMO advices the Federal Executive Council (FEC) as part of the approval process for individual projects. The project teams consult the DMO for approvals before involving the multilateral agencies such as International Finance Corporation (IFC), Multilateral Investments Guarantee Agency (MIGA) or International Development Agency (IDA) for provision of guarantees or other financial instruments.

\subsubsection{Highways Act 1971}

The Act vests the powers of management, direction and control of Federal highways throughout Nigeria in the Minister of Works and Housing, in respect of planning (including research and designing of Federal highways), the construction and maintenance, the supervision of users of such highways and the regulation of traffic thereon. The Act empowers the Minister to erect, equip and maintain toll gates on any Federal highways as and when required, with the approval of the President. ${ }^{6}$ In other words, the Minister of Transportation is saddled with the responsibility of constructing and operating toll gates and collect tolls on the Federal roads. Invariably where

\footnotetext{
Ibid s 6 \& s 7

${ }^{2}$ The World Bank (2011) Project Appraisal Document 56

${ }^{3}$ Ibid

4 'States Bankruptcy: End of the Road for State Creation?' (Thisday, Nigeria, 2 Nivember, 2011), P. 21.

${ }^{5}$ Afego, Pyemo; 'Between Debt and Sustainable Development,'(Businessday, Nigeria 20 June, 2012), p. 23.

${ }^{6}$ Highways Act 1971, s2
} 
there is concession of federal roads that need tolling, the consent of the Minister in charge will be required. Unfortunately, the main infrastructure legislation, ICRC Act, does not contain a saving provision with regard to this piece of legislation, nor does it make a reference to the Highways Act.

\subsubsection{Utilities Charges Commission Act, 1992}

This Act establishes the Utilities Charges Commission, defines its functions and powers, and provides with respect to its administration and related matters. The Commission shall among other things:

a. evaluate and advice the Federal Government on tariffs charged by any of the public utilities listed in the Second Schedule of the Act;

b. design and develop an adequate information system relating to the Scheduled Utilities and their tariffs charges;

c. monitor charges and tariffs and propose

The implication of this is that the approval of the Commission may be required in fixing the tariffs between the private investor (concessionaire) and the Government. ${ }^{1}$ The Schedule of the Act mentions specific utilities: NEPA, NITEL, NNPC, Nigerian Airways, NRC, Ferry Services Organizations, Nigerian Ports Authority, Road Transport Organisations, NIPOST and such others as the Commission determines from time to time. ${ }^{2}$

\subsubsection{Fiscal Responsibility Act, (FRA) 2007}

The objectives of the Fiscal Responsibility Act are to:

- Provide for the prudent management of the nation's resources.

- Ensure long-term macro-economic stability of the national economy.

- Secure greater accountability and transparency in fiscal operations within a medium-term fiscal policy framework.

- Establish the Fiscal Responsibility Commission (FRC) to ensure the promotion and enforcement of the nation's economic objectives and for related matters.

The word 'fiscal' relates to accounts or management of revenue and public finances of government. 'Fiscal responsibility' therefore addresses issues of aggregate fiscal discipline, allocative and operational efficiencies and covers the entire life of fiscal policies and processes from programming, planning and budgeting. Prior to the debt relief gained by Nigeria in 2005, the issue of fiscal responsibility and prudent management of the country's public resources were merely economic lexicons common only among elite economists working in the public sector, or public finance experts who criticized government fiscal policies using the language. ${ }^{3}$

The Fiscal Responsibility Act, 2007 established the Fiscal Responsibility Commission ${ }^{4}$ which has the mandate under the Act to: ${ }^{5}$

- Compel any person or government institution to disclose information relating to public revenues and expenditure; and cause an investigation into whether any person has violated any provisions of the Act.

- Monitor and enforce the provisions of the Act.

- Disseminate such standard practices including international good practice that will result in greater efficiency in the allocation and management of public expenditure, revenue collection, debt control and transparency in fiscal matters.

The Fiscal Responsibility Act, 2007 mandates the Debt Management Office to maintain a comprehensive, reliable and current electronic database of internal and external public debts and guaranteeing public access to the information. The FRA also mandates the President to within 90 days from the commencement of the Act and with advice from the Minister of Finance set overall limits for the amounts of consolidated debt of the Federal, State and Local Governments pursuant to the provisions of items 7 and 50 of Part 1 of the $2^{\text {nd }}$ Schedule to the Constitution.

Managing debt, the Medium-Term Expenditure Framework and annual budgets, maintaining macroeconomic stability, managing fiscal situation prudently, keeping the budget deficit at 3 percent and cutting recurrent expenditure especially overheads and infrastructure renewal are all in line with the provisions of the Fiscal Responsibility Act, 2007.

Section 51 of the FRA guarantees legal capacity to any person to enforce its provisions by obtaining prerogative orders or other remedies at the Federal High Court without having to show any special or particular interest. $^{6}$

\subsubsection{The National Planning Commission Act, 2007}

This Act establishes the National Planning Commission (NPC) with responsibility for promoting national unity and integration through formulating and coordinating national plans for infrastructure development. The NPC

\footnotetext{
${ }^{1}$ O Soyeju, 'Legal Framework for Public Private Partnership in Nigeria' https://scielo.org.za accessed $28^{\text {th }}$ January 2022

2 'What is the Legal Framework for Concessions in Nigeria? https://detailsolicitors.com accessed $28^{\text {th }}$ January 2022

${ }^{3}$ Jim-Nwoko, Ugo; 'Imperatives of Fiscal Responsibility Commission,' (Businessday, Nigeria 17 November, 2011$)$, p. 14.

${ }^{4}$ FRA 2007, s1

${ }^{5}$ Ibid, s3

${ }^{6}$ FRA Act, 2007 s51
} 
has more of a macroeconomic than project-oriented function and its role seems limited to coordinating projects within an overall master plan framework and prioritizing projects within the overall capital budget of the Federal Government. Section 2 of the National Planning Commission Act provides, amongst other things, that the Commission shall:

- Focus on key national development issues and suggest ways for their efficient resolution.

- Determine how best the Fundamental Objectives and Directive Principles of State Policy contained in the Constitution of the Federal Republic of Nigeria 1999 can achieve the major objectives of optimal development and suggest amendments that may be required, from time to time, to achieve those objectives in the light of encountered realities.

- Provide a national focal point for the coordination and formulation of national policies and programmes.

- Draw up, from time to time, national economic priorities and programmes and map out implementation strategies.

- Coordinate the formulation and implementation of government programmes as contained in annual plans, budgets, medium-term and perspective plans at the federal, state and local government levels.

- Enhance the efficiency of public sector spending and general national economic management.

- Continuously visualise the international economic system in target horizons and identify the activities likely to become dominant or strategic globally.

- Determine how Nigeria can best adapt to realise the objective set out in paragraph (i) of this section and compete effectively in the global system.

There is no mention of PPP within the Act but clearly the ICRC will need to coordinate its activities with the NPC.

\subsection{Existing Sector Laws}

A number of Acts were passed before the country's economic reform programme was introduced and which placed emphasis on the public sector delivering infrastructure services. These include:

- $\quad$ The Federal Airports Authority of Nigeria Act, 2004.

- $\quad$ The Civil Aviation (Repeal and Re-enactment) Act, 2006.

- The National Inland Waterways Authority Act, 2004.

- The Water Resources Act, 2004.

- The Nigerian Railway Corporation Act, 1955.

Laws which anticipated the reform programme and specifically provided for the private sector to deliver infrastructure and utility services included:

- The Nigerian Communications Act, 2003.

- $\quad$ The Nigerian Ports Authority Act, 1999.

- $\quad$ The Electric Power Sector Reform Act, 2005.

Two agencies, Nigerian Electricity Regulatory Commission (NERC) and the National Communication Commission (NCC) were established to regulate private activities in the electricity and energy sector, and telecommunication services, respectively, pursuant to the EPSRA and NCC Act.

\subsection{Fallouts from Privatisation and PPP in Nigeria}

There were some positives to the privatisation exercise in Nigeria since 1999. The privatization and commercialization programme was responsible for a raft of other policies that boosted private sector investment in Nigeria. They include the Communications Policy and Nigeria Communications Commission Act which ushered in the telecoms revolution; the pensions contributory scheme and Pensions Reform Act which was a fallout of the pensions liabilities BPE was confronted with in the course of restructuring and privatizing public enterprises; the oil and gas reform programme, leading to the drafting of the Petroleum Industry Bill; a comprehensive Transportation Policy framework and draft transport sector bills meant to usher in the intermodal transport system; the Landlord Port model; the Anti-Trust and Competition Act of 2019; and the power sector reform programme that led to the enactment of the Electric Power Sector Reform Act, establishment of the Nigerian Electricity Regulatory Commission and subsequent unbundling of NEPA/PHCN and sale of electricity distribution and generating companies to private investors.

\subsection{Conclusion}

Despite a growing campaign in recent time to entice investors to the country's PPP sector with the aim of mobilising private finance, increasing the efficiency of capital investment, improving service delivery, optimising the use of existing infrastructure and improving available technical expertise, only few states in Nigeria have succeeded in establishing an efficient PPP model. The absence of suitable PPP structure and viable financial models, lack of access to affordable finance, the volatile political economy, and consumers' 
unwillingness to pay for services have contributed to weaken investors' interest in PPPs. There must be detailed studies and financial modelling to determine tariffs, transfers and subsidies and state governments must be willing to invest in infrastructure as and when required. Though there are available funds for investments globally, these funds should be structured to encourage the private sector to access at affordable rates. ${ }^{1}$

There appears to be no coherence in the legal framework for PPPs in Nigeria. Most of laws overlap without any clear-cut demarcations in the responsibilities of the agencies created. The enabling instruments of the MDAs need to be amended to accommodate agencies such as the ICRC in order to make for synchronization in functions.

ICRC Act, PPA, the Public Enterprises (Privatisation and Commercialisation) Act, Debt Management Office Act, Fiscal Responsibility Act, Nigerian Ports Authority Act and sector legislations (existing and proposed) will need to be amended or news laws enacted in order to:

i. Ensure that public authorities are empowered to enter into agreements for the implementation of privately financed infrastructure projects and can delegate their statutory functions to private companies.

ii. Ensure that the regulation and licensing of private sector operators and operations is transparent, timely and effective.

iii. Provide appropriate remedies for protecting the safety and integrity of public infrastructure from vandalism and other criminal activity.

iv. Ensure that there are no distortions created by existing tax, banking, company or any other laws that would bias the investment decisions of public authorities for or against PPP as a procurement option, or distort the commercial decisions of PPP investors, contractors, or operators.

v. Provide for transparent, efficient and competitive procurement procedures for PPP-type contracts that encourage innovation from bidders, allow dialogue to optimize the allocation of risks between the contracting parties.

vi. Ensure that there is an effective dispute resolution process which can operate independently and in a timely manner to provide alternative procedures such as arbitration and expert determination.

vii. Ensure that the proposed institutional and financial framework for PPP projects and the issuance of guarantees, partial risk insurance or other financial instruments by, or through, the federal government is consistent with the Fiscal Responsibility Act 2007 and corresponding legislation proposed in each state.

\subsection{Recommendations}

Public Private Partnership is very important and that is why government must ensure that there are adequate materials available to facilitate and enable proper development of PPP. For instance, making provision for a strong framework for the private sector in order to boost their confidence in the scheme.

Also, public views should be sought and well managed. The general public should be properly informed, educated and oriented. The public awareness and steady dissemination of information should be upheld at large.

The political, regulatory and economy should be stabilized and the capital market developed in such a way that it will fit in and meet the requirements for PPP projects.

In order to ensure and achieve greater participation in infrastructural development in Nigeria, the government should amend the laws, enhance regulations and institutions or improve the environment. It is the expectation that the enactment of specific laws on privately financed projects will encourage private sector participation in the provision of better infrastructures to the community.

\footnotetext{
1 'Experts Advise Water Investors on Concessioning, Full Divestiture,' Businessday (01-07-2014), p. 28.
} 